Beamish, D., 2003, Characterising landfills from the air. First Break, Vol. 21, No.10, October 2003. 67-72.

\title{
Characterising landfills from the air
}

The British Geological Survey (BGS) continues to highlight the need for, and environmental relevance of, modern, multi-sensor airborne geophysical data in the UK. Here David Beamish, geophysicist with the BGS, describes the electromagnetic component of such survey data and how it may be used to characterise landfills from the air.

\section{Introduction}

The first recorded municipal landfill site was opened by officials in the city-state of Athens some 2,500 years ago. Today in the UK, waste and landfill is a multi-billion pound business. The science of landfill is technically complex and the subject of sustainability debates. The geophysical characterisation of a landfill may provide us with simple measures of complex processes. Four case studies of airborne electromagnetic data applied to the characterisation of landfills, at various points in their life-cycles, are presented.

\section{Landfill}

Landfill is the controlled deposit of waste to land. Historically the degree of control and regulation applied to landfill was either non-existent or marginal. The last 30 years has seen the topic emerge on every conceivable front so that waste and sustainability issues appear, quite rightly, in government targets and in regulatory directives.

Landfills sites can be considered as artificial dynamic (i.e. biologically and chemically reactive) systems. When waste degrades under anaerobic (oxygen-free) conditions in a landfill, breakdown by bacteria produces gas and soluble chemicals. The main gases produced are methane and carbon dioxide. Landfills are now recognised as the UK's largest man-made source of methane releases to the atmosphere. Unit for unit, methane has a greater global warming potential than $\mathrm{CO} 2$ and is one of the main causes of the greenhouse effect. The soluble chemicals combine with liquids to form landfill leachate.

It is possible to define three classes of landfill: (1) Dilute and disperse landfill. Wastes are buried with minimum or no artificial containment. Degradation processes are maintained by rainwater input and natural attenuation processes operate and are governed by the existing (site specific) hydrogeological system. Many historical legacy sites fall into this category, (2) Contain and seal landfill. These are more modern highly engineered sites in which a great deal of attention is paid to leachate/gas generation, isolation and containment and (3) Bioreactor (or flushing) landfill. Waste degradation is accelerated to enhance biogas generation for energy applications and/or to minimise the completion time to inert, nonhazardous, conditions. 
Modern licensed sites are highly engineered. The purpose of the waste management system is to contain the waste products and, ultimately, render them inert and environmentally safe. A requirement for monitoring on the scale of decades to perhaps 100 years, and greater, is an inevitable consequence of the strategy. The geophysical assessment of landfills (predominantly legacy sites) using ground-based techniques is well established. One of the clearest associations is that between high electrical conductivity and accumulations of leachate material. Given the material complexity of a landfill system (it is a three-phase system comprising solid, liquid and gas), the bulk electrical conductivity should offer a simple and effective summary of the combined effects of numerous geochemical and biological processes.

\section{AEM Surveys}

Finland is one of the few countries in the world to have undertaken a modern nation- wide airborne geophysical survey of its territory. The survey has been conducted using a geophysically instrumented aircraft (a Twin-Otter) developed by the Geological Survey of Finland (GTK). Although mineral exploration forms a key incentive for the work, recent years have seen the airborne systems increasingly used for environmental applications throughout Europe. Along with other, helicopter-based airborne systems, the main data sets provided include magnetic (including gradiometer), radiometric and active electromagnetic (EM) data components. The airborne EM (AEM) data, acquired by the fixed-wing system, currently comprise coupling ratios between vertical coplanar coil pairs at two frequencies ( 3 and $14 \mathrm{kHz}$ ). Sampling along the flight line is typically between 10 and $15 \mathrm{~m}$ for flight speeds of about $200 \mathrm{~km} / \mathrm{hr}$. In order to provide appropriate geophysical information, one- dimensional conductivity models (half-space and/or multilayer) are constructed from the coupling ratios.

In 1999, the GTK Twin-Otter was used in a set of trials to acquire the UK's first detailed AEM data in addition to magnetic gradiometer (wing-tip) and radiometric information. Environmental targets, across four limited areas in the East Midlands, included colliery zones in north Nottinghamshire, together with a series of active and closed landfills. The trial AEM data, together with existing data from Finland, have enabled an initial assessment of the utility of AEM data in relation to life-cycle assessments of a variety of modern (active) and legacy (closed) landfills. Four of these case studies are now described.

\section{The Ämmässuo landfill}

Two AEM surveys, in 1993 and 1997, were carried out over the Ämmässuo landfill in southern Finland. The landfill is a large (1.5 km2) Municipal Solid Waste (MSW) facility situated to the west of Helsinki. An aerial view of the five cell structure is shown in Figure 1. Cell 4 is reserved for biological waste and cell 5 is under construction. The landfill is built on bedrock comprising highly resistive FennoScandinavian granitic shield. Operation of the multi-cell landfill began in 1987 and in 1997, 467,000 tons of waste were tipped, largely within three active cells (1, 2 and 3). At the time of the surveys discussed here there was no leachate 
recirculation. All landfill fluids were channelled through drains and pumped over 6 $\mathrm{km}$ to a sewage works for treatment. In 1995, midway between the two surveys, the conductivity of the landfill drainage fluid was in excess of $500 \mathrm{mS} / \mathrm{m}$ showing increases (not continuous) over the period between the two surveys. The AEM results relate to an active containment landfill following 6 and 10 years of operation.

The two airborne surveys of 1993 and 1997 used N-S flight lines with a line spacing of about $100 \mathrm{~m}$. The flight lines were about $5 \mathrm{~km}$ in length and flight altitude varied between 25 and 35 meters. In 1993, the AEM system operated at only one frequency $(3 \mathrm{kHz})$ and the single frequency data form the basis of the study over the 4 year time span. Conductivity models were obtained from the survey data using a 1D non-linear least-squares inversion procedure that generated the best fitting half-space at each sampled data point.

Figure 2a shows the 1997 flight lines across a $2 \times 2 \mathrm{~km}$ area centred on the five cells of the landfill. Figure $2 \mathrm{~b}$ shows the conductivity model obtained from the 1993 survey. Maximum values of $170 \mathrm{mS} / \mathrm{m}$ are observed in cell 1 (single peak) and cell 2 (double peak). The contour scale, common to all the plots, shows low level variations in the range from 2.5 to $20 \mathrm{mS} / \mathrm{m}$ using cross-hatch. Conductivity values in excess of $20 \mathrm{~ms} / \mathrm{m}$ are confined to the landfill cells while values in excess of 2.5 $\mathrm{mS} / \mathrm{m}$ are confined to the operational area of the landfill. It should be noted that the bedrock conductivity is much less than $1 \mathrm{~ms} / \mathrm{m}$ (typically 0.1 to $0.2 \mathrm{~ms} / \mathrm{m}$ ). The single contoured area outside and to the north of the landfill delineates an area of stockpiled clays. The conductivity model for the 1997 survey (Fig. 2c) shows major increases in conductivity and a redistribution of peak values, which now exceed 300 $\mathrm{mS} / \mathrm{m}$ in cell 1 . In cell 2 , the existing two peak distribution migrates west and develops into a single concentration encompassing the majority of the cell. Although an existing concentration appears in cell 3 in 1993, there appears to be no major change in leachate generation over the four year period. This is confirmed when the conductivity differences are examined. The conductivity differences (Fig. 2d) are formed by subtracting the 1993 model from that of the 1997 model. All significant conductivity differences, formed by the subtraction, are increases. The ability to contour conductivity differences down to the level of $2.5 \mathrm{mS} / \mathrm{m}$ provides an indication of the consistency of the two data sets.

Clearly the results presented confirm that there is no geophysical evidence of significant lateral leakage from the operational landfill cells. The result is in accord with regular monitoring of surface and groundwater, which indicate that no groundwater contamination is present. The time-lapse study demonstrates that major changes in leachate generation and mass transport occur, and can be broadly defined within the individual cells of an operational landfill, by the AEM method.

\section{The Barnstone Landfill}

By way of contrast, an operational municipal landfill in the East Midlands was located in one of our trial BGS/GTK survey areas. Here near-surface geological complexity is the norm and the conductive targets are located in a highly conductive, clay-rich environment. Although such material is highly appropriate for a landfill location (it offers a barrier to geochemical transport), the bulk 
conductivity of some of the formations exceeds that of the waste within the landfill of the previous example.

The $4 \times 1.5 \mathrm{~km}$ Langar survey area (Fig. 3a) was flown using $50 \mathrm{~m}$ E-W flight lines at a nominal elevation of $40 \mathrm{~m}$. The geological context of the survey area is shown in Figure $3 b$. In the NW, the Mercia Mudstone Group (MMG) provides a contact with the Lower Lias Barnstone Member along a major break in slope (C1, Fig. 3b). The Barnstone Member then provides a contact with the clay-rich Barnby Member along a further break in slope (C2, Fig. 3b). As can be seen in the conductivity model in Figure $3 c$, the three geological units are all approximately represented by different values of conductivity. A number of low amplitude perturbations are associated with roads and a set of very high conductivity $(>300 \mathrm{mS} / \mathrm{m}$ ) localised anomalies are found in association with works, landfills and farms. Two landfills (labelled L1 and L2) are located within the area and both used former quarry sites. L1 (Langar Tip Bingham) operated between 1953 and 1971 and is now capped with permeable soils (i.e. it is operating as a dilute and disperse former landfill). A simple localised increase in conductivity is apparent in the conductivity results of Figure $3 \mathrm{c}$. A peak conductivity value of $380 \mathrm{mS} / \mathrm{m}$ is obtained using the low frequency halfspace model shown here. Thus, a detectable level of conductive material is apparent some 28 years after closure. Landfill L2 (Barnstone Tip) is a 5 cell operating structure and is one of the smaller MSW facilities available within Greater Nottingham. During the year of the AEM survey it accepted 45,000 tons of waste.

Since the survey was undertaken using a flight line spacing of $50 \mathrm{~m}$, it has been possible to examine quite detailed information. Figure 4 shows a $1 \times 1 \mathrm{~km}$ area in the vicinity of landfill L2 looking NE. Figure 4a shows an aerial photograph draped on topography with the 5 cell structure superimposed. The structure is multi-mode with the oldest cell (1) now closed and operating in dilute and disperse mode. The remaining cells are more modern containment structures in which leachate is recirculated. Cell 4 is full and due to be capped while cell 5 is a proposed expansion unit. Figure $4 \mathrm{~b}$ shows the conductivity model, again draped on topography. It is evident that the landfill is by no means the largest conductivity anomaly detected by the survey. This award goes, in fact, to the cement works situated just to the west of the landfill with a peak value in excess of $1000 \mathrm{mS} / \mathrm{m}$. Landfill cell 1 is capped by permeable soils and conductivity values within this cell are similar to those of the older closed landfill (L1, Fig. 3). It is evident that conductivity values > $250 \mathrm{mS} / \mathrm{m}$ are confined to the landfill site itself. Given the nature of the geology it is difficult to ascribe any wholly geochemical significance to conductivity variations below this level.

Further closed legacy landfill sites, such as the Langar Tip discussed above, were also surveyed as part of a larger trial area in northern Nottinghamshire. In this area, the geology largely comprises the Sherwood Sandstone Group. The sandstone, with near- surface conductivities consistently less than $15 \mathrm{mS} / \mathrm{m}$, provides a more favourable environment for the detection of geochemically-enhanced and therefore conductive concentrations of pore waters. As can be seen in the next two examples, the threshold detection level of the AEM technique is significantly increased. 


\section{The Warsop Landfill}

The landfill at Oakfield Lane, Warsop is typical of many closed landfill sites. The history of the site is largely unknown and no complete records of the waste materials deposited are available. The landfill is estimated to have operated between 1930 and 1976. The landfill occupied a former quarry on the edge of Warsop. It is now covered with a capping of permeable soils and no additional engineering is apparent. The AEM results relate to a dilute and disperse landfill some 23 years after closure.

The landfill was part of an area surveyed using 'regional' flight line separations of $200 \mathrm{~m}$. At this scale of AEM surveying, smaller scale features within the landscape may not be adequately resolved or they may go undetected. Seven regional flight lines, across a $1 \times 1.5 \mathrm{~km}$ area in the vicinity of the landfill, are shown on an aerial view in Figure $5 \mathrm{a}$. Although the full extent of the former quarry and landfill are not known, the central flight line forms a traverse across the likely centre of the structure. A half-space conductivity model based on the high frequency data is shown in Figure $5 \mathrm{~b}$. Due to the flight line separation and the compactness of the anomaly, a bulls-eye effect is observed. Contours are only displayed where values exceed $20 \mathrm{mS} / \mathrm{m}$. The lowest contoured interval ( 20 to $30 \mathrm{~ms} / \mathrm{m}$ ) is shown in crosshatch and it is evident that the detection level of the landfill response is $30 \mathrm{mS} / \mathrm{m}$. The peak value of the high frequency model shown in Figure $5 b$ is about $160 \mathrm{mS} / \mathrm{m}$. The model obtained from the low frequency data shows a very similar form with a reduced peak value of about $90 \mathrm{mS} / \mathrm{m}$.

An E-W ground traverse of the site using an EM ground conductivity (coil-coil) system with coil separations of 10,20 and $40 \mathrm{~m}$ has confirmed that the amplitude and scale of the airborne results agree with ground-based data. A vertical electric sounding at the site has provided greater detail on the depth distribution of conductive material that generates the AEM response. The sounding reveals a conductive plume $(60 \mathrm{~ms} / \mathrm{m})$ between depths of 1 and $23 \mathrm{mbgl}$. The size of the AEM conductive anomaly is large when compared to other closed dilute and disperse sites of similar age in the area. It is suggested that there is likely to be a relationship between conductivity models derived from AEM data and the level of ongoing bioreactivity within a post closure landfill. In the context of this argument, the Warsop landfill appears highly reactive.

\section{The Peafield Lane Landfill}

The Peafield Lane landfill exists in a rural setting and was operated for only 13 years between 1977 and 1992. The site of some $0.6 \mathrm{~km}^{2}$ occupied a former quarry and the maximum permitted waste (inert and industrial) was some $0.6 \mathrm{~m} 3$. The site was operated under the dilute-and-disperse principal and is capped by permeable soils. The site lies in a trial survey area covered by $\mathrm{E}-\mathrm{W}$ flight lines with a line spacing of $50 \mathrm{~m}$. It is therefore possible to examine and model the data in some detail. The AEM results relate to a small scale dilute and disperse landfill some 10 years after closure.

A $1.5 \times 1.5 \mathrm{~km}$ perspective map view of the site is shown in Figure 6a. The Peafield Land landfill (L1) occupies the central southern area as shown by the database 
polygon (in cross-hatch). A further two landfill polygons were 'discovered' on the basis of their conductivity response. Landfill $L 2$ is identified by a polygon (again in cross-hatch) in the NE of the area shown; a further landfill (L3) exists to the east and south-east of the area. The main cultural feature in the selected area is a road traversing the ridge. The conductivity model obtained from the high frequency data is shown in Figure $6 \mathrm{~b}$. It has been possible to provide a lower bound of $15 \mathrm{mS} / \mathrm{m}$ (transition from grey to colour) that isolates the main conductive zones within the area. The localised anomaly along the road is attributed to the route of an $11 \mathrm{kEv}$ cable; a bifurcation in the anomaly (Fig.6b, top) follows the cable route.

It should be noted that, in this example, the conductive zones provide only marginal increases above the background (clean sandstone) values. The maximum increase, associated with the main landfill (L1), is only a factor of 2 to 3 above background. There is an obvious association between all 3 landfills and conductivity enhancements in the model. The main Peafield Lane landfill appears to be a 3 cell structure. We have no details of the landfill construction but there is a progressive conductive enhancement downslope.

Thus far the information obtained from the AEM data has been displayed as halfspace conductivity models at one of the two frequencies currently available. The information essentially forms a conductivity distribution map. The full nature of the data and the models pertaining to them is, however, intrinsically volumetric. The higher frequencies probe a shallower volume than the lower frequencies. With multi- frequency EM data it is always possible to construct multi-layer models. This can be undertaken even with only two frequencies but the vertical resolution must be acknowledged to be crude. A variety of mathematical modelling experiments have been carried out to optimise the procedures (regularised inversion) for the type of data and targets under consideration. Figure 7 shows a volumetric presentation of the one- dimensional inversion models obtained from the two frequency data at the Peafield Lane site. The volume shown is $1500 \times 1500 \times 60 \mathrm{~m}$ so that a high degree of vertical exaggeration is required.

The model contains conductivity variations of between 1 and $50 \mathrm{~ms} / \mathrm{m}$. Values less than $22.5 \mathrm{mS} / \mathrm{m}$ are made transparent so that the image displays only higher conductivity variations as a set of isosurfaces. A single horizontal depth slice is shown at the approximate depth of the water table $(25 \mathrm{~m})$. This opaque slice displays conductivity values of about $10 \mathrm{mS} / \mathrm{m}$ (see colour scale). The results indicate that the at- and near-surface conductive zones, associated with all 3 landfills, are vertically compact and isolated from the aquifer.

\section{Conclusions}

Landfills, both old and new, pose potential environmental hazards. In terms of the prevailing regulatory framework, a form of lifetime prediction and monitoring of mass transport phenomena needs to be undertaken. Four case studies of AEM survey data applied to landfill characterisation have been presented. Modern municipal landfills, when active, offer difficulties of scale and operational hazards that can be circumvented by the application of airborne techniques. The various case studies, offering a range of life-cycle assessments of between a few years of operation and some 28 years after closure, indicate a broad range of application. 
The prevailing geological context inevitably sets a detection threshold. The bulk electrical conductivity determined geophysically offers a summary of the combined effects of complex processes. Such a simple measure may be useful in defining the reactive state of both active and closed landfills.

\section{Acknowledgements}

The BGS wishes to thank the GTK aerogeophysical team for their dedication and professionalism during the survey operations. We are grateful to the Department of the Environment, Transport and the Regions and the Environment Agency for their co-sponsorship of the acquisition of the UK survey data. This report is published with the permission of the Executive Director, British Geological Survey (NERC).

\section{Figure Captions.}

Figure 1. Aerial view of the Ämmässuo Municipal Solid Waste landfill in southern Finland, looking from south to north. Numbers indicate the five cells.

Figure 2. Time lapse study of the Ämmässuo landfill using low frequency ( $3 \mathrm{kHz})$ AEM data. Polygons indicate landfill cells. The same contour-scale is used for results shown in (b), (c) and (d). (a) Plan view of the 5 cell structure with $1997 \mathrm{~N}-\mathrm{S}$ flight lines superimposed. (b) Conductivity model obtained from 1993 data. (c) Conductivity model obtained from 1997 data. (d) Conductivity difference model (1997 model minus 1993 model).

Figure 3. The Langar survey area $(4 \times 1.5 \mathrm{~km})$ in the East Midlands and AEM results obtained. L1 and L2 indicate the two landfills discussed in the text. (a) Perspective view of Ordnance Survey 50k base map (

Perspective view of geological map draped on topography. C1 and C2 indicate breaks in slope. (c) Conductivity model draped on topography obtained from low frequency survey data. Gray colour indicates no data.

Figure 4. Detail $(1 \times 1 \mathrm{~km})$ from the Langar survey centered on the active Barnstone landfill. (a) Aerial photograph draped on topography with 5 cell structure superimposed. (b) Conductivity model (low frequency) draped on topography.

Figure 5. The Warsop former landfill in northern Nottinghamshire. Area shown is 1 x $1.5 \mathrm{~km}$. (a) Aerial view with seven E-W flight lines, spaced at $200 \mathrm{~m}$, indicated. (b) Conductivity model obtained from high frequency survey data, with aerial view as background. Values below $20 \mathrm{mS} / \mathrm{m}$ not contoured.

Figure 6. The former Peafield Lane landfill in northern Nottinghamshire. Area shown is $1.5 \times 1.5 \mathrm{~km}$. (a) Perspective view of Ordnance Survey 50k base map ( $\square$ Crown Copyright. All rights reserved), draped on topography. Three former landfills (L1, L2 and L3) are indicated (cross-hatch polygons). (b) Perspective view of conductivity model obtained from high frequency survey data, draped on topography. 
Figure 7. Conductivity model obtained by 1D regularised inversion of the two frequency AEM survey data for the Peafield Lane landfill. Results are shown as a 3D perspective view across a $1.5 \times 1.5 \mathrm{~km}$ area (same as previous) to a depth of $60 \mathrm{~m}$. Conductivity values less than $22.5 \mathrm{mS} / \mathrm{m}$ are made transparent Higher conductivity values appear as isosurfaces. A single opaque horizontal slice is also shown at a depth of $25 \mathrm{~m}$. 
Figure 1. Aerial view of the Ämmässuo Municipal Solid Waste landfill in southern Finland, looking from south to north. Numbers indicate the five cells.

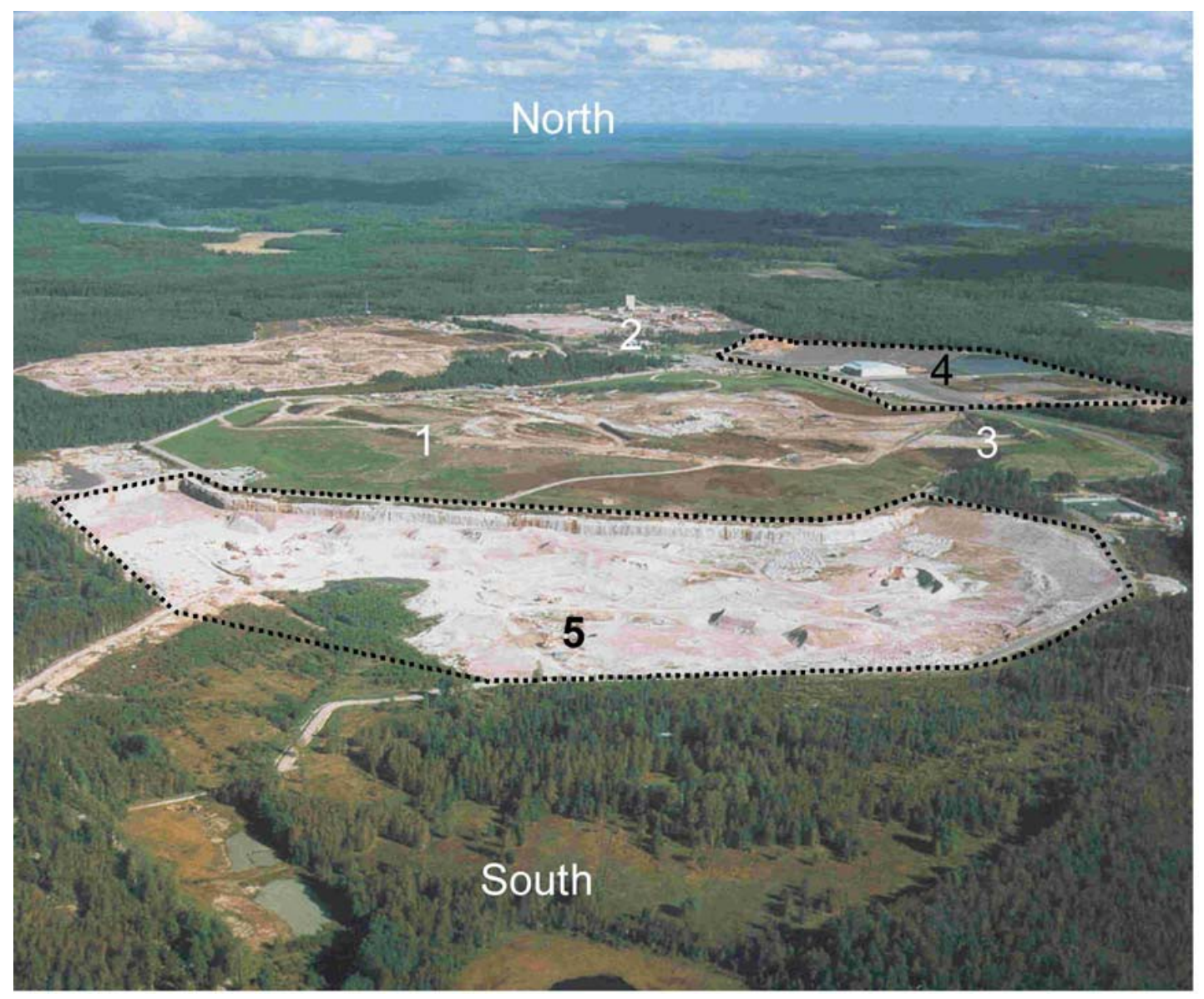


Figure 2. Time lapse study of the Ämmässuo landfill using low frequency (3kHz) AEM data. Polygons indicate landfill cells. The same contour-scale is used for results shown in (b), (c) and (d). (a) Plan view of the 5 cell structure with $1997 \mathrm{~N}$-S flight lines superimposed. (b) Conductivity model obtained from 1993 data. (c) Conductivity model obtained from 1997 data. (d) Conductivity difference model (1997 model minus 1993 model).
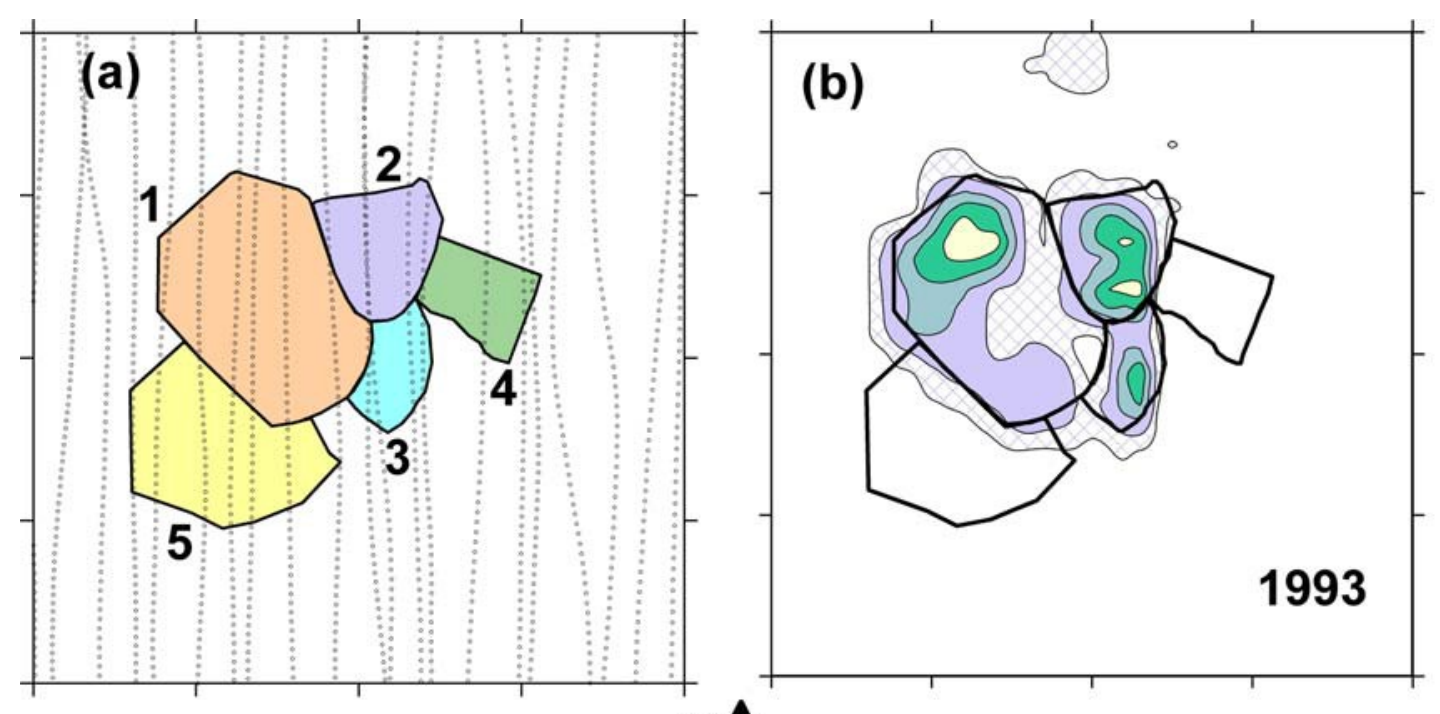

$\mathrm{N} \uparrow$
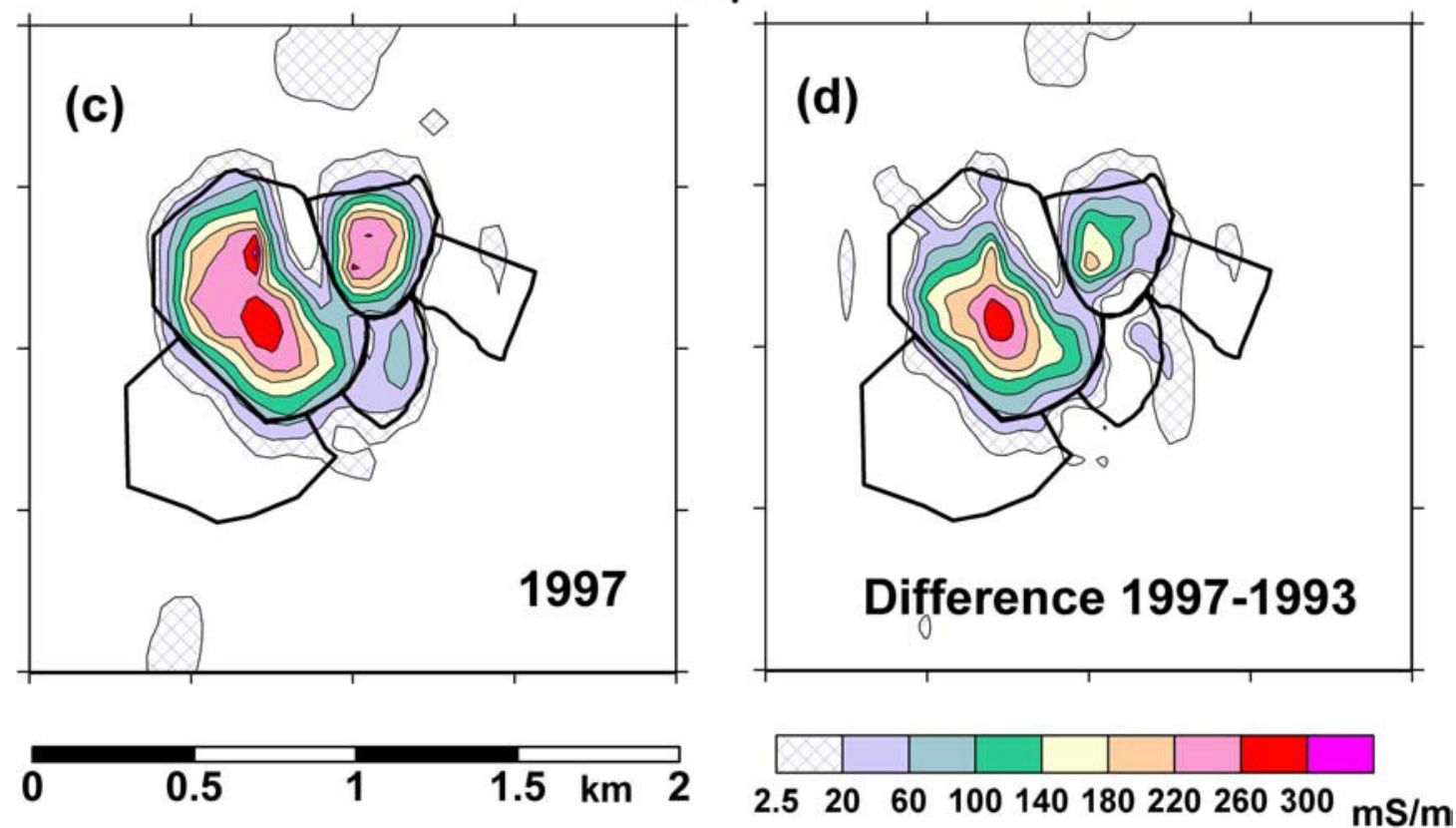
Figure 3. The Langar survey area $(4 \times 1.5 \mathrm{~km})$ in the East Midlands and AEM results obtained. L1 and L2 indicate the two landfills discussed in the text. (a) Perspective view of Ordnance Survey 50k base map (@Crown Copyright. All rights reserved). (b) Perspective view of geological map draped on topography. C1 and C2 indicate breaks in slope. (c) Conductivity model draped on topography obtained from low frequency survey data. Gray colour indicates no data.

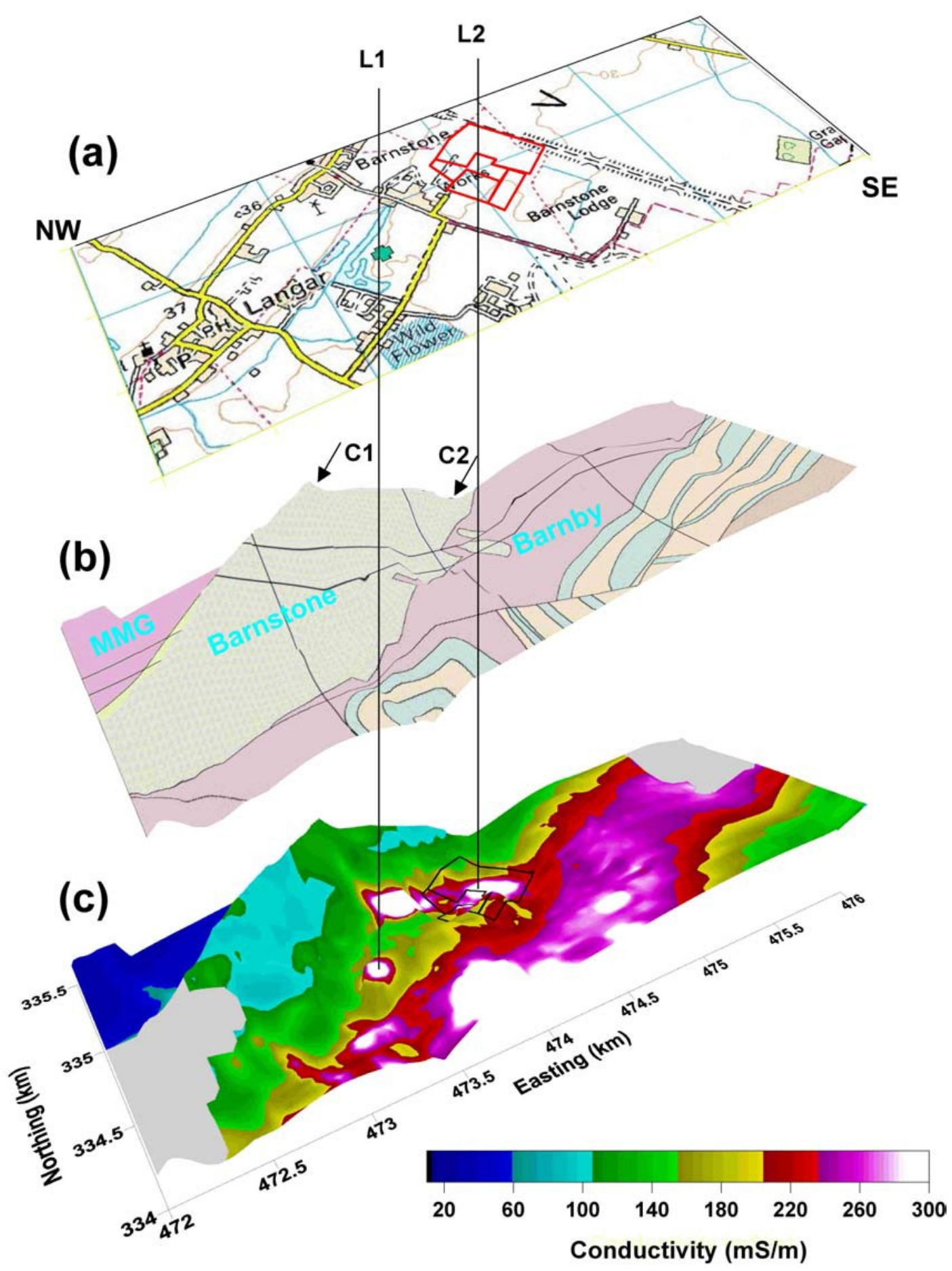


Figure 4. Detail (1 x $1 \mathrm{~km})$ from the Langar survey centered on the active Barnstone landfill. (a) Aerial photograph draped on topography with 5 cell structure superimposed. (b) Conductivity model (low frequency) draped on topography.

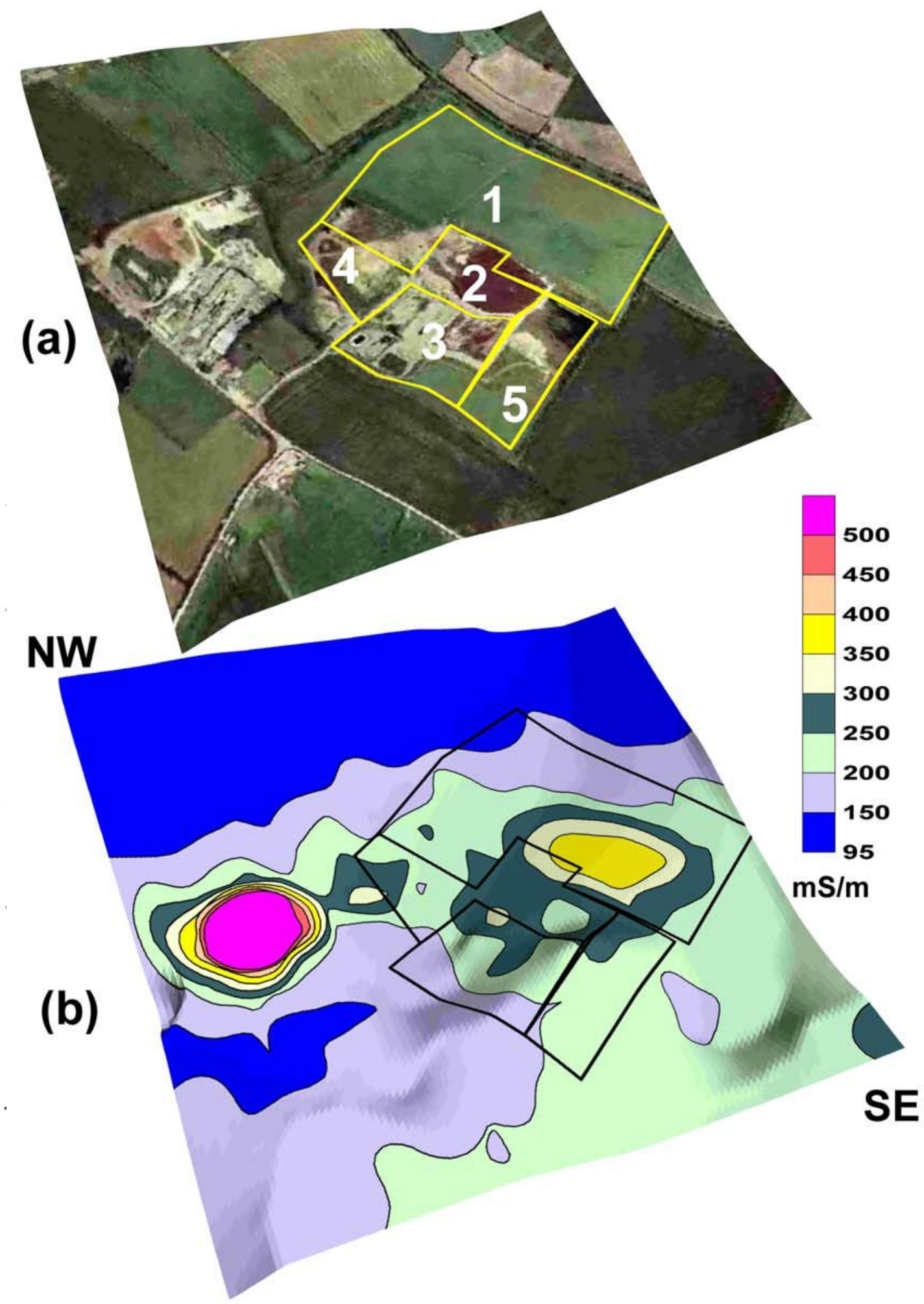


Figure 5. The Warsop former landfill in northern Nottinghamshire. Area shown is 1 x $1.5 \mathrm{~km}$. (a) Aerial view with seven E-W flight lines, spaced at $200 \mathrm{~m}$, indicated. (b) Conductivity model obtained from high frequency survey data, with aerial view as background. Values below $20 \mathrm{mS} / \mathrm{m}$ not contoured.

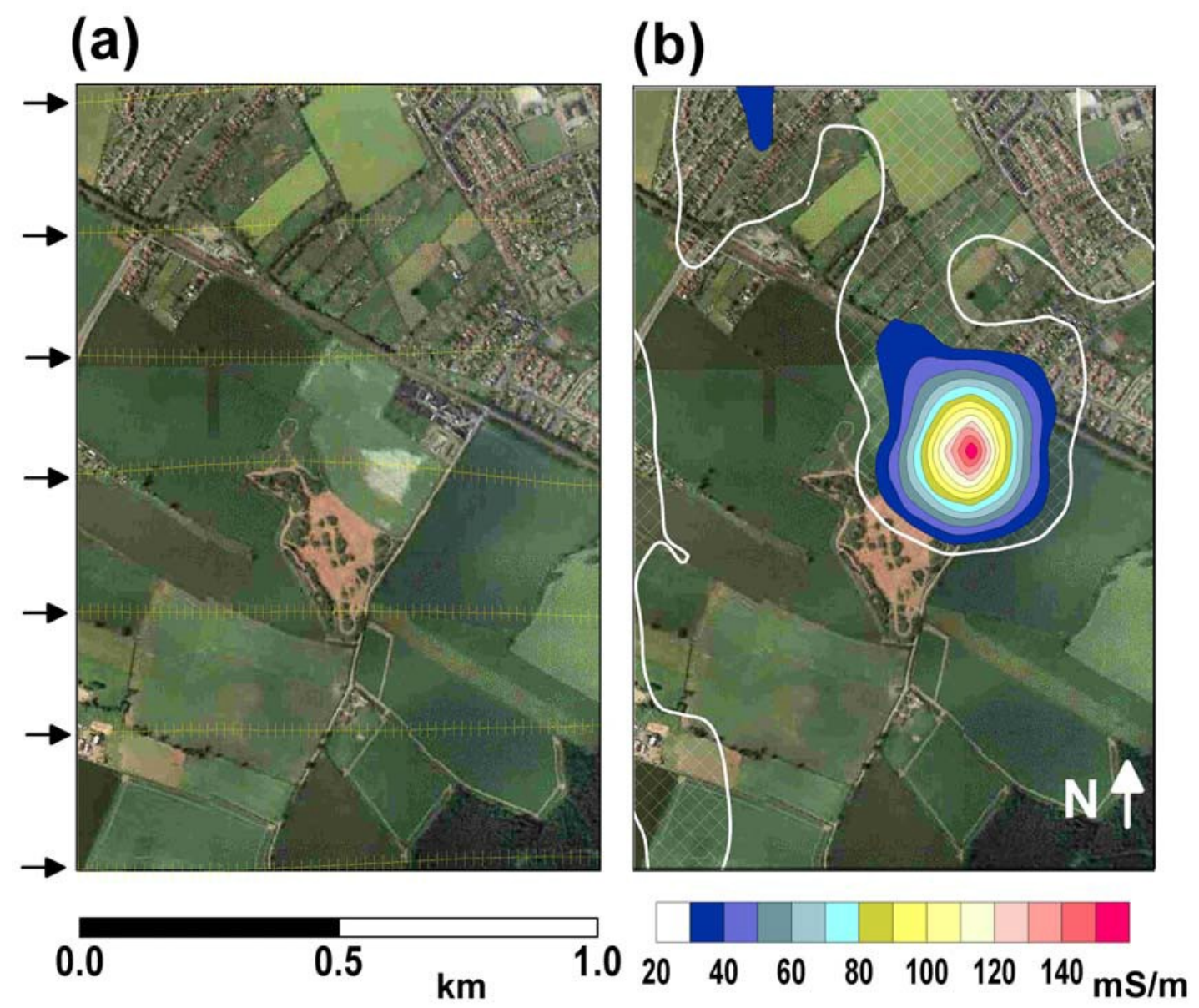


Figure 6. The former Peafield Lane landfill in northern Nottinghamshire. Area shown is 1.5 x $1.5 \mathrm{~km}$. (a) Perspective view of Ordnance Survey 50k base map ( (C) Crown Copyright. All rights reserved), draped on topography. Three former landfills (L1, L2 and L3) are indicated (cross-hatch polygons). (b) Perspective view of conductivity model obtained from high frequency survey data, draped on topography.
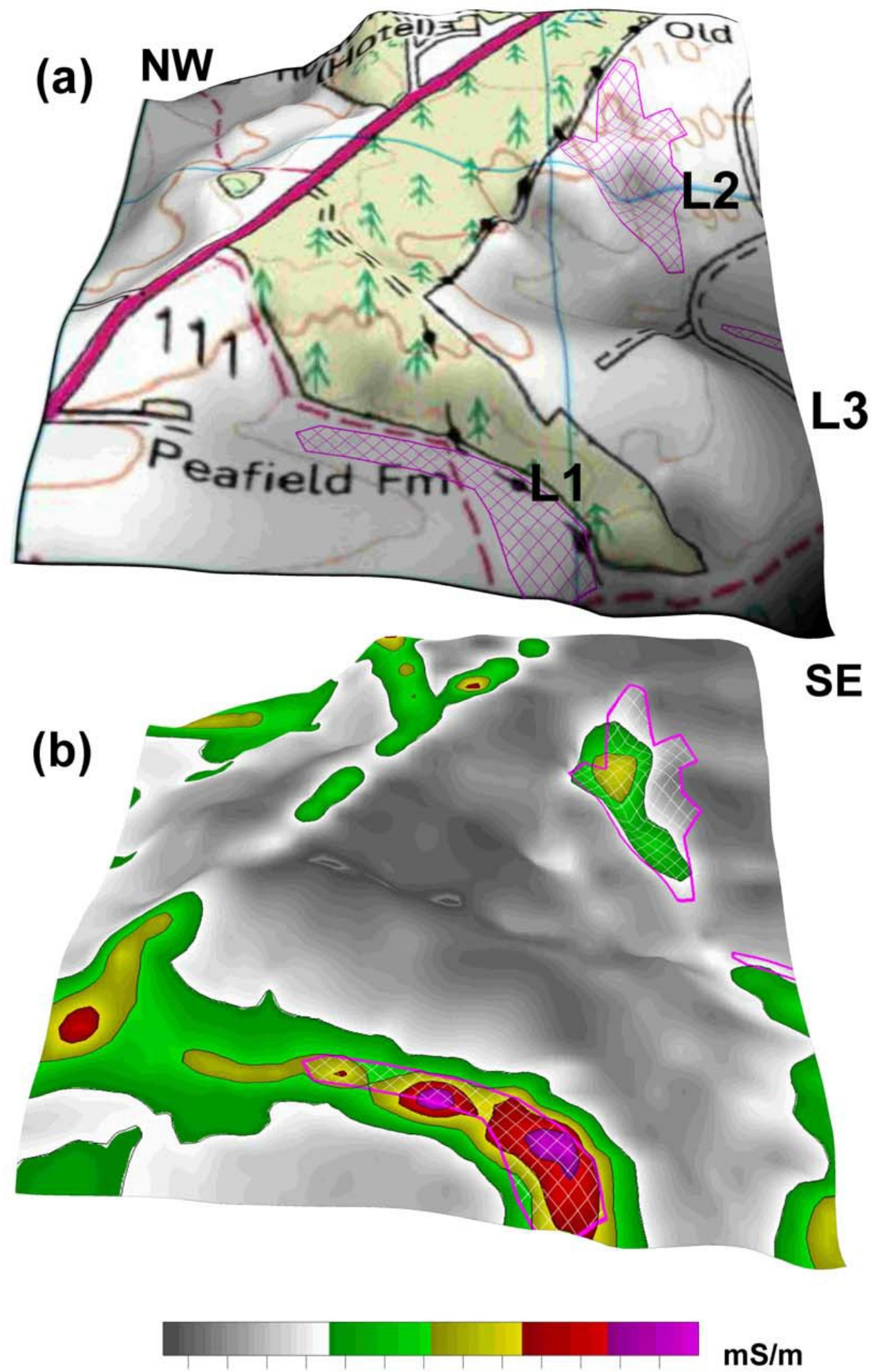

8101214161820222426283032 
Figure 7. Conductivity model obtained by $1 \mathrm{D}$ regularised inversion of the two frequency AEM survey data for the Peafield Lane landfill. Results are shown as a 3D perspective view across a $1.5 \times 1.5 \mathrm{~km}$ area (same as previous) to a depth of $60 \mathrm{~m}$. Conductivity values less than $22.5 \mathrm{mS} / \mathrm{m}$ are made transparent Higher conductivity values appear as isosurfaces. A single opaque horizontal slice is also shown at a depth of $25 \mathrm{~m}$.

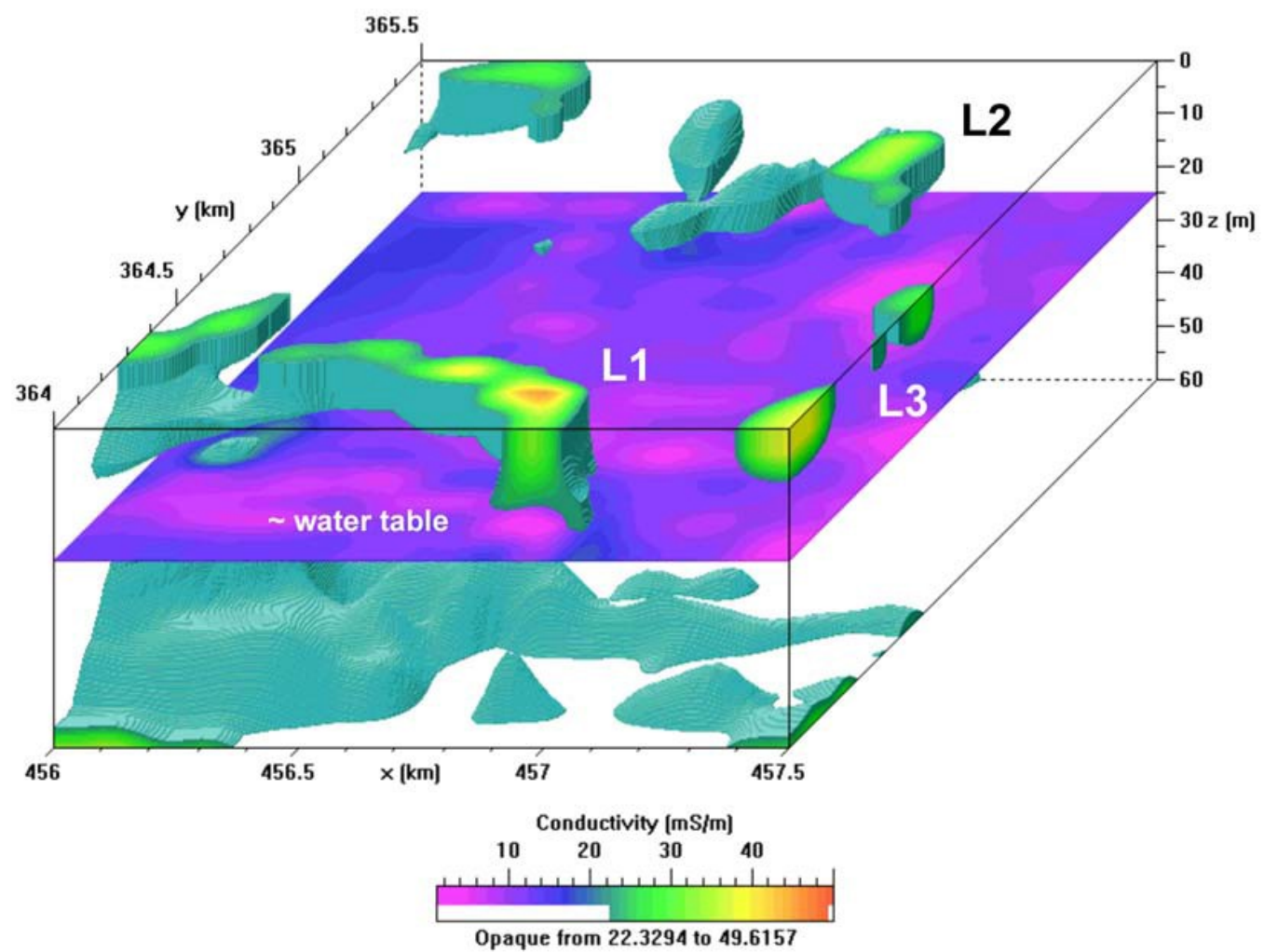

